\title{
Green Economics: setting the scene. Aims, context, and philosophical underpinning of the distinctive new solutions offered by Green Economics
}

\author{
Miriam Kennet* \\ Green Economics Institute \\ 6 Strachey Close, Tidmarsh \\ Reading, RG8 8EP \\ E-mail: greeneconomicsinstitute@yahoo.com \\ *Corresponding author
}

\section{Volker Heinemann}

166 Divinity Road

Oxford, OX4 1LR

E-mail: volkerheineman@yahoo.de

\begin{abstract}
Green Economics positions economics within a very long-term, earth-wide, holistic context of reality as a part of nature. It also incorporates and celebrates 'difference', diversity, equity and inclusiveness within its concepts of society and community. Its philosophy is to manage economics for nature as usual, rather than to manage the environment for business as usual.

The paper introduces the new Green Economics discipline and reviews its shape and philosophical underpinnings. By combining economics with knowledge from the natural sciences, we argue that Green Economics can incorporate a much wider, more practical, multidisciplinary range of knowledge than other schools of economics.

The paper suggests how Green Economics can offer unique insights into four of the key areas ('eco', intellectual, political and moral) of today's significant and mounting problems and highlights how its novel insights provide new solutions.

The development of this new branch of Economics is justified in this text by reviewing the main contradictions, deficiencies, assumptions, conventions, and inherent normative concepts to be found in dominant neo-classical economic thinking, which have accumulated over the past two centuries.
\end{abstract}

Keywords: Green Economics; ecological economics; environmental economics; environment; sustainability; social and environmental justice; holistic; methodology; long-term; specificity; philosophy.

Reference to this paper should be made as follows: Kennet, M. and Heinemann, V. (2006) 'Green Economics: setting the scene. Aims, context, and philosophical underpinning of the distinctive new solutions offered by Green Economics', Int. J. Green Economics, Vol. 1, Nos. 1/2, pp.68-102.

Biographical notes: Miriam Kennet is a member of Mansfield College, Oxford University and currently researching at Oxford Brookes into the supply chain and stakeholder theory from a Green Economics perspective. Her research at South Bank University, London and at Templeton College, Oxford University focused on Green issues and strategic management of international firms. 
She is coeditor (with Molly Scott Cato), of one of the few books on Green Economics, Green Economics, Beyond Supply and Demand to Meeting People's Needs, and author of articles on corporate backlash and supply chain issues, including the reduction in supplier base diversity and transparency. She is co-founder and Director of the Green Economics Institute, a member of the Chartered Institute of Purchasing and Supply (MCIPS) and founder and Editor of the International Journal of Green Economics.

Volker Heinemann is an Economist who studied at the Universities of Goettingen, Kiel and Nottingham. He is a Specialist in international and developing economics, monetary economics and macroeconomic theory and policy. He is the author of the book Die Oekonomie der Zukunft, (The Economy of the Future), a book outlining the principal structure for a modern economy that accepts the pressing changes required to the outdated current economic thinking. He is co-founder and Director of the Green Economics Institute, a member of the Institute of Chartered Accountants in England and Wales and Associate Editor of the International Journal of Green Economics.

\section{Introduction: Green Economics innovation}

The paper sets the scene for the development of Green Economics and describes how this new 'Green Economics' school of thought is beginning to take shape and sets out to explore its aims, its roots and philosophical underpinnings. It critiques neo-classical economics from a Green Economics perspective, proposing reform where it is needed. Green Economics brings to economics the core drivers of ecology, equity, social and environmental justice; and the paper traces the development and contribution of these ideas through its sister disciplines, such as welfare economics, feminist economics, eco-feminism, eco-socialism, environmental economics and ecological economics.

The paper also describes its distinctive methodology and innovation. The significant and increasing problems of today are grouped into four headings (ecological/economical, intellectual, political and moral), which Green Economics particularly addresses with new insights.

Green Economics is distinctive in six ways that build on much older ideas, which have evolved to be influenced by the full spectrum of more recent thinking. These ways are:

1 enlightenment ideas of reason, imagination and memory (Jevons, 1871;

Walras, 1865)

2 critical theory (Habermas et al.)

3 ideas about structure and institutions (Veblen et al.)

4 some post-modern concepts (Derrida and Soja)

5 feminist theories (Kuiper and Nelson)

6 eco-feminist ideas (Salleh et al.) 
These allow Green Economics to examine reality by means of multidisciplinary, complex, holistic, and very long-term methods as well as to take into account the political and social aspects. The range provides an opportunity to frame economics both within the natural sciences, (which mainstream economists have been striving to achieve with limited success), and also within the social sciences. It reorients modelling approaches so they are congruent with natural science processes, and it embraces the context of more verbal narrative. The range particularly brings political economy, moral sentiments, and ethics back within its borders.

The aim of Green Economics is to create a new discipline that works for the benefit of all people everywhere, for the planet, the biosphere, non-human species, nature, and other life forms. Green Economics integrates ideas and theories, which are also designed to help end the systemic and institutional causes of inequity and poverty.

It therefore takes an inclusive approach, promoting fairness, equity, participation, freedom, democracy with social and environmental justice at its core. Rather than simply working for individuals (and their preferences) or the requirements of powerful private corporations, it is developing a new mix of needs and rights that will ensure genuine very long-term sustainability, survivability, well-being and happiness for all people everywhere, always within the limits and comfort of nature.

\section{The four categories of significant and increasing problems that Green Economics is designed to address: eco, intellectual, political and moral}

As Green Economics and archaeology remind us, 'civilisation' and mainstream economics are post-Ice Age phenomena. Climate instability is predicted to create unprecedented conditions more hostile to society; and the very survival of our society or our species starts to become uncertain. Mainstream economics tends to limit its focus to short-term concerns. Green Economics, with its precautionary principle, works to prevent foreseeable, adverse effects on people and nature. Green Economics is able to do this also because it is inherently more aligned with the natural sciences and many of its practitioners are trained in natural sciences and archaeology, as well as economics. As a consequence of adopting a very long-term view of events, intergenerational equity and the rights of future generations are integral. Not surprisingly, Green Economics strongly advocates the need for each generation to leave behind an adequate bundle of resources and a habitable planet. Mainstream economics is still too bound up with concerns of price, profit, economic growth and the perspective of the owners of production versus the workers and therefore entirely fails to grasp this new reality. 
Figure 1 The green economy and its complexity

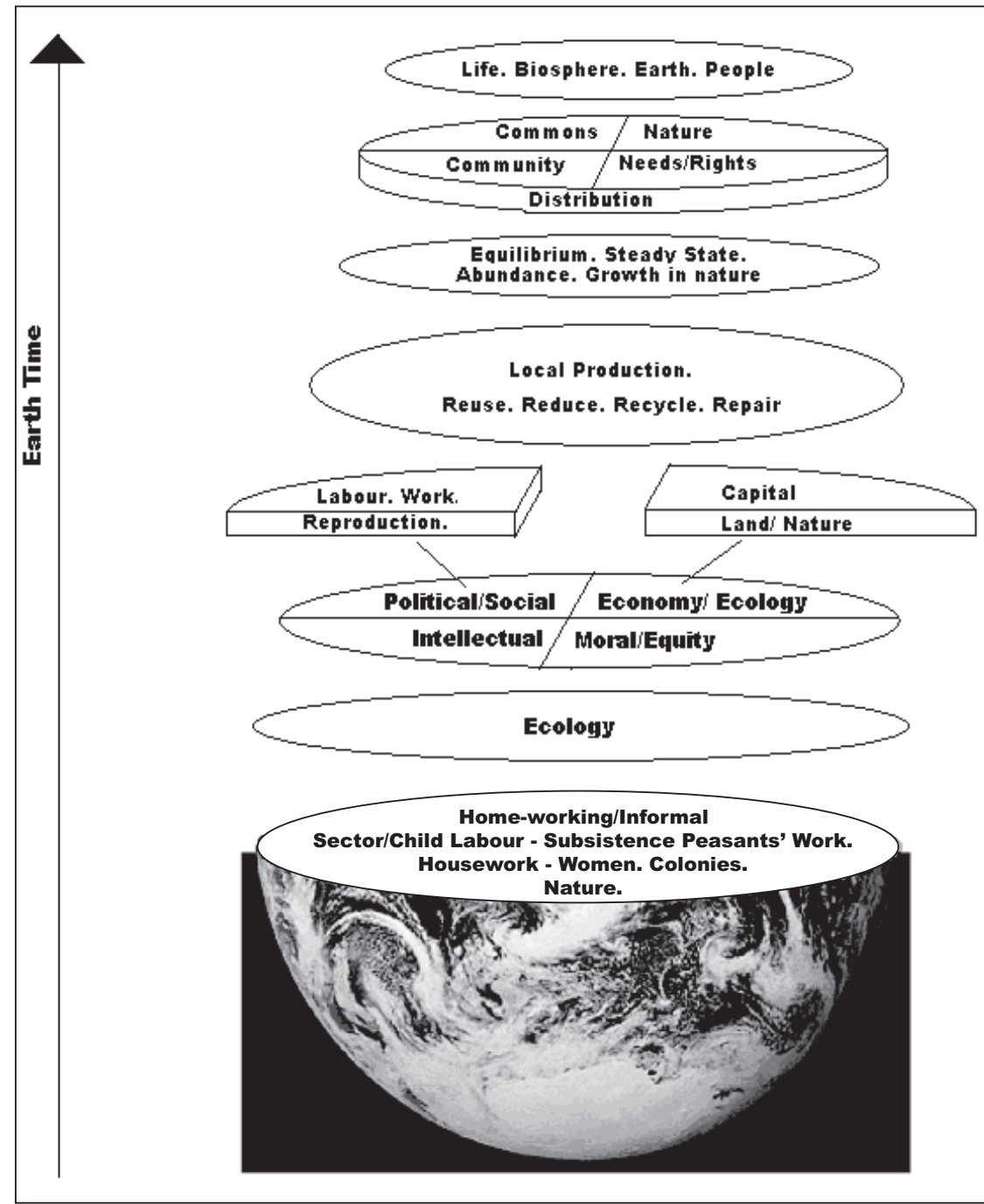

Source: Kennet and Kennet (2006)

Green Economics methodology also brings new perspectives to conventional economics tools, in terms of both time and space. This new context enables it to reveal, disentangle, and unravel the power relationships and vested interests in the new global marketplace. The logic of Green Economics advocates local production for local needs, and reusing, reducing, repairing and possibly recycling, rather than global expansion of corporations. Thus, wisdom and holism are re-introduced into economic problem solving. It also re-incorporates political economy and the moral and transformational aspects of the economics of Smith (1776), while offering new solutions to 'managing the commons', which has been often restricted to game theoretical models (von Neumann and Morgenstern), and exercises based on the prisoner's dilemma or voting issues (Arrow, 1951). 
Attitudes to nature are completely revised. According to Goldsmith (2005), economics needs to keep within nature's carrying capacity and at the moment many of its systems are being so overloaded with the impacts of human economic activity that cannot continue. It is time to 'Rewrite Economics' (Goldsmith, 2005) for the benefit of humans and the natural world and to accept the boundaries imposed by the earth. This new rationality and wisdom leads to an economics of increasing abundance as produced in nature, rather than an economics of scarcity.

The most pressing current problems are grouped into four main categories, with the advantages of the Green Economics approach explained. They are ecological/economical, intellectual, political and moral.

Table 1 Green Economics distinctive methodology and basic concepts

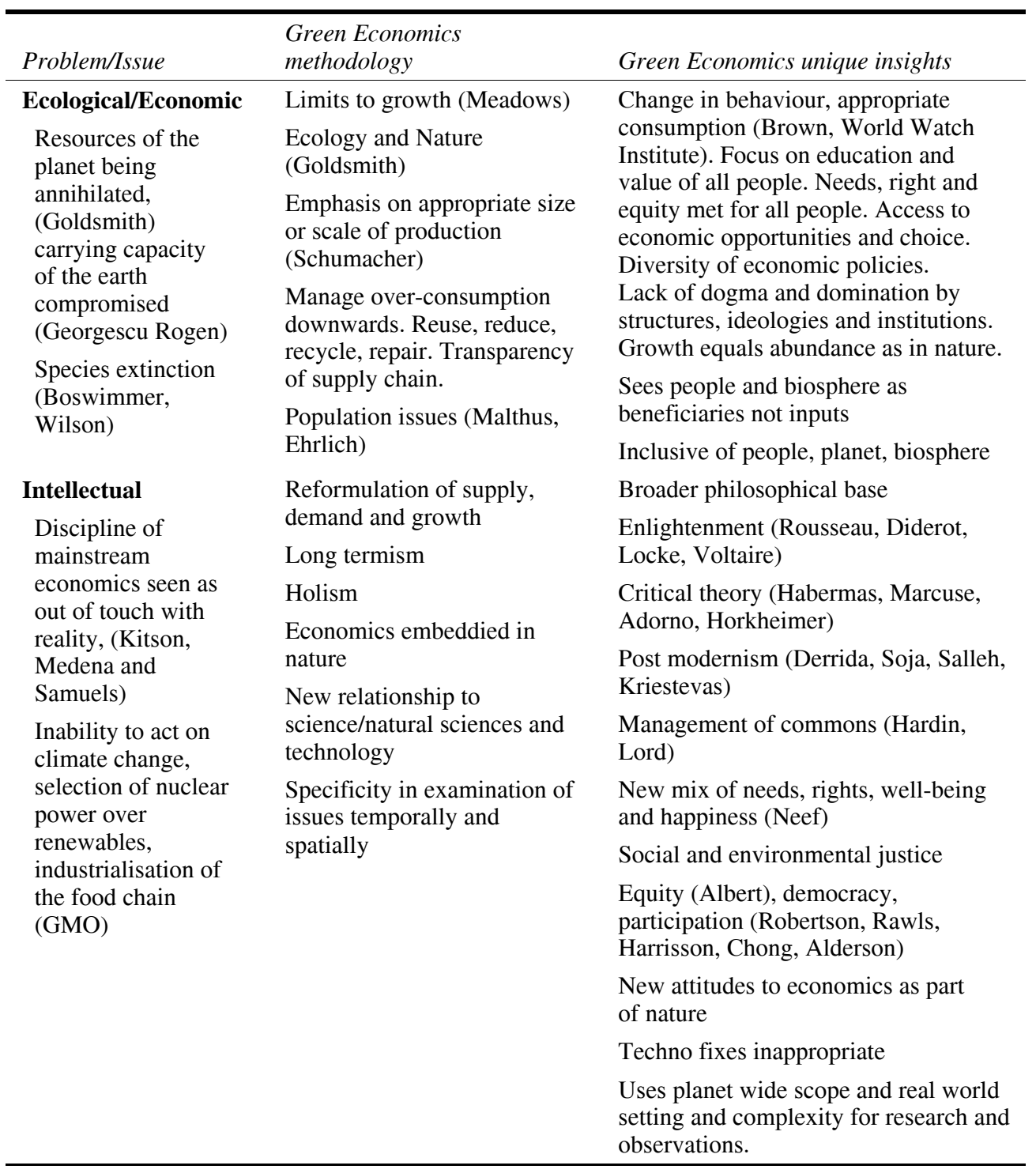


Table 1 Green Economics distinctive methodology and basic concepts (continued)

\begin{tabular}{|c|c|c|}
\hline Problem/Issue & Green Economics methodology & Green Economics unique insights \\
\hline \multirow{4}{*}{$\begin{array}{l}\text { Political } \\
\text { Undemocratic, } \\
\text { untransparent power of } \\
\text { multinationals, global } \\
\text { institutional power, } \\
\text { weak local economies }\end{array}$} & \multirow{4}{*}{$\begin{array}{l}\text { Progress in the economy } \\
\text { measured by new indicators, } \\
\text { well-being, quality of life, } \\
\text { sustainability, long termism } \\
\text { etc., examination of power } \\
\text { structures }\end{array}$} & Deconstructing power relationships \\
\hline & & $\begin{array}{l}\text { Increased role of regional/local } \\
\text { economies, communities, access }\end{array}$ \\
\hline & & Inclusive approach \\
\hline & & Intergenerational equity \\
\hline \multirow{2}{*}{$\begin{array}{l}\text { One-half of all work } \\
\text { not valued or included } \\
\text { in GDP }\end{array}$} & \multirow{2}{*}{$\begin{array}{l}\text { Reform/replace of global } \\
\text { institutions to provide global } \\
\text { governance. }\end{array}$} & $\begin{array}{l}\text { Re-embeds the economy in nature } \\
\text { and the social system }\end{array}$ \\
\hline & & $\begin{array}{l}\text { No longer axis of worker versus } \\
\text { owner }\end{array}$ \\
\hline \multirow{3}{*}{$\begin{array}{l}\text { Moral } \\
\text { Problem of world } \\
\text { poverty ( } 1.3 \mathrm{bn} \text { out of } \\
6.3 \mathrm{bn} \text { global } \\
\text { population in extreme } \\
\text { poverty) (Sachs) }\end{array}$} & $\begin{array}{l}\text { Regional and locally diverse } \\
\text { and democratic solutions }\end{array}$ & \multirow{2}{*}{$\begin{array}{l}\text { Priority given to ending poverty and } \\
\text { enabling equity rather than through } \\
\text { same patterns of industrialisation } \\
\text { and development or conventional } \\
\text { growth. }\end{array}$} \\
\hline & $\begin{array}{l}\text { Using analysis of power } \\
\text { relations and institutions } \\
\text { (Veblen, Foucault, Gramsci) }\end{array}$ & \\
\hline & \multirow[b]{2}{*}{$\begin{array}{l}\text { Feminist analysis of patriarchy } \\
\text { and accumulation. (Mies, } \\
\text { Mellor, Kuiper, Salleh) } \\
\text { Critique of trickle down } \\
\text { theories. Wealth creation } \\
\text { locally with local power and } \\
\text { decisions. }\end{array}$} & \multirow[b]{2}{*}{$\begin{array}{l}\text { Reform of global institutions to } \\
\text { reflect specific local conditions, } \\
\text { requirements and individual choices } \\
\text { by people and communities. Social } \\
\text { and environmental justice (Lord, } \\
\text { Sen) Poverty as unfreedom. Reform } \\
\text { of aims of economy, continued } \\
\text { inequality problems with human } \\
\text { happiness directly addressed. }\end{array}$} \\
\hline $\begin{array}{l}\text { Inadequate markets, } \\
\text { corruption and crime. } \\
\text { Non-beneficial trades: } \\
\text { arms, prostitution, } \\
\text { drugs }\end{array}$ & & \\
\hline
\end{tabular}

\subsection{Eco-ecological/economic}

It is becoming increasingly evident that the resources of the planet are being annihilated (Goldsmith, 2005), plundered (Gruhl, 1975) and disturbed at such a rate that even mainstream economic observers are starting to accept that the free inputs they rely on from nature will soon cease to be available. There is a growing consensus that the conditions of the natural world, so long regarded as abundant and available to be raided, are becoming scarce (Broswimmer, 2002, p.1). He cites the distinguished biologist Wilson (1992), who found that 100 species are disappearing everyday and he investigates the sociological and economic underpinnings of what he calls this 'Ecocide' (Broswimmer, 2002, p.3). He shows how this actually constitutes only the fourth mass extinction in earth history, (the first three being, Permian - 250 million years ago, Paleozoic - 200 million years ago, Dinosaur - 65 million years ago), Mithen (2003, p.247) suggests that there may have even been another anthropogenic mega-fauna extinction in $11500 \mathrm{BC}$ caused by the Clovis hunters, which wiped out most of the mammoths, mastodons and giant sloths. Broswimmer (2002, p.105) argues that "it is the very lack of democratic participation in the economic sphere that lies at the root of the possibility that homo sapiens may be a very much shorter-lived species than the dinosaurs who managed to last 120 million years". We argue here that mainstream economics provides no analytical framework to counter or even address such problems. 
Similarly, natural conditions, such as global climate, are changing and are becoming more challenging and more hostile to humanity. Our 'civilisation' and its globalised neo-classical economic activities are therefore also vulnerable economically to such effects, which include increased intensity and severity of cyclones, hurricanes, (Hurricane Andrew cost \$16,000 million) typhoons, floods, tsunamis and heatwaves, such as those in France in 2004 with 14800 deaths (Brown, 2004, p.xxv) etc. (Houghton, 1997, p.3). Anthropogenic increases in carbon dioxide were up from $316 \mathrm{ppm}$ in 1958 to 369 in 1998 and will have created warming parameters of between $1.4^{\circ} \mathrm{C}-5.8^{\circ} \mathrm{C}$ by 2100 (Maslin, 2004, p.146). Costs of damages due to climate change are predicted by the UN at $\$ 150$ billion a year by 2010 (Brown, 2004). This should cause alarm bells to ring as the distinguished Intergovernmental Panel on Climate Change, the largest panel of scientists ever to work on an issue, in its IPCC Report of 1997 showed that the global average temperature difference between the coldest part of the Ice Age and a warm interglacial is only about five or six degrees (Houghton, 1997, p.8). There are also consequential sea level rises of up to $88 \mathrm{~cm}$ predicted by 2100 (Maslin, 2004, p.146). Archaeology informs us that our civilisation and agriculture only began at the end of the last Ice Age - we have no notion of our economic survivability in a changed climatic situation.

We argue that as a consequence, this kind of data is highly relevant to the economic theory and that all of the evidence points to the fact that our economic systems must therefore adapt to operating within a 'suitable carrying capacity' of the earth. Pegging the level of that capacity should be a pressing subject for economic debate, as well as determining where the balance of intended beneficiaries should lie among the planet, human species, non-human species or nature. Green Economics addresses these questions and re-embeds the economy firmly within ecological and social structures. It therefore de-commodifies society and nature.

The Greek word 'Oikia' or house, is the root of both economics and ecology. Economic growth, progress and development are measured by indicators in Green Economics that describe them as forms of 'creation' mimicking the abundance of nature, not 'annihilation' of resources (Goldsmith, 2005). Profit, prices, markets and competition are regarded as incidental, rather than drivers of the economic system. Green Economics treats people (not labour power), the planet, nature, non-human species, and the biosphere as beneficiaries, not just resources or economic factors of production. The aim is to ensure that they are all as well-off following an economic transaction as they were before it.

This new discipline operates on the principle that the needs of people and natural systems must be simultaneously satisfied, and achieves this by redefining progress in economics to mean that all these requirements are met. The purpose of products is to satisfy needs, not to enhance the power of people or corporations or states, which means political and institutional analyses are key. Global industrialism, according to Dobson (2000, p.27), is regarded with suspicion. Mies's (1994) ideas about the new subsistence economy and Hines's (2000) Localisation thesis refocus the global economy around local markets. The meaning and welfare value of products is questioned, as well as their transformation into forms of identity and above all, their necessity. Gigantism and globalisation are seen as agents of oppression. Green Economics is multidisciplinary with 'fuzzy' boundaries since it reduces its reliance on ceteris paribus and embraces the complexity, irreversibility and uncertainty found in the real and life-world. 
Equilibrium should no longer reflect only price concerns but also advantage/disadvantage/impacts and effects in political/social, moral and ecological terms. In this way, Green Economics acts as a filter for other systems as it is non-dogma, and does not seek to impose one system or style globally, as in capitalism or Marxism, but rather advocates diversity using a Green Economics analysis for each situation. It replaces the axis of the dualism of the worker versus the owner of production with concern for people, society, non-human species, nature and the biosphere as a holistic whole, life-world.

\section{Demand and supply}

Green Economics also reformulates the concepts of Demand and Supply. According to the Worldwatch Institute (Brown, 2004), increasing demand, as stimulated and promoted by neo-classical economic logic is manifesting itself in the form of over-consumption in richer countries and is directly contributing to our failure to live within the carrying capacity of nature. This consumption stimulation, Green Economics would argue, is highly irresponsible. Green Economics is reformulating the concept of demand in making consumption effective, not stimulating it, and also bringing in supply-side realism (Kennet, 2004; Scott Cato and Kennet, 1999). That includes efficiencies in the distribution issues of transparency, equity and complexity and embedded human, social and environmental costs and impacts, which cannot be replaced by simple technology developments, end-of-pipe fixes or Economies of Scale. Green Economics therefore also researches into associated distribution and stakeholder effects and brings ethics, complexity, diversity, locality, and transparency into its analysis of the supply chain (Kennet, 2004; 2005a).

\subsection{Intellectual}

Secondly, many practitioners of conventional economics are disappointed and critical of their own discipline, according to Medena and Samuels (1996) and Omerod (1994). "The subject has become so obscure that even orthodox economists are bemoaning its intellectual poverty," says Kitson (2005) in the Cambridge Journal of Economics. They are alienated, and unconvinced by the results generated by mainstream economic models. Mainstream economists thus observe that their work has little bearing on the real 'life-world' or on ending poverty (Kitson, 2005), and disagreement is growing. However, disciplinary insurgence is rare because of the limited professional progress that usually follows rebellious action. Unfortunately, many well-known economists, for example, Pasinetti (2005) and popular commentators, for example, Sachs (2005) continue to advocate a more intensified business as usual approach, whereby growth, more profit, increasing theoretical elegance, and the increased economic hegemony of global corporations are promoted. Green economists argue that these solutions do not solve the problems of today. Clearly, mainstream economics remains strait-jacketed by the modern positivist stance it still openly adopts and embraces, in much the same way that modern architectural approaches (such as too much 'Le Corbusier' and not enough human and natural consideration) result in alienating structures that fail to appropriately address the problems of today. 


\subsubsection{Long-Termism}

Green Economics takes a view that is much longer-term than the short business cycles found in neo-classical and business school economics. Due to its consideration of the effects of a transaction on the 200 000th generation and beyond (Myers, 1985), Green Economics can draw from history, palaeontology (glacial-interglacial cycles lasting 40000 years) (Maslin, 2004) and archaeology. As a consequence, Green Economics does not simply discount the future, and even restitution for future generations could be considered. Future generations should not be unduly disadvantaged through the mass extinction and climate change currently underway. Intergenerational equity is investigated by such writers as Alderson (2006) who is greatly influenced by Chong in the current volume (2006). Instead of mobilising the resources of the planet in support of human kind, we must surely mobilise the resources of human kind in support of the planet. This postulates a revision of our value systems, social paradigms and consumption culture (Myers, 1985).

Harrison (1992) argues that we might want to be remembered as the generation that made a difference by shifting the earth back into balance, and reconciling the needs of present and future humans and other species, instead of creating waste monuments and a 'garbage mausoleum one to four thousand times our body weight'.

Green Economics takes an even longer perspective, from the long-term past through anthropology, archaeology and environmental science and uses this knowledge to filter its analysis of economic decision-making.

\subsubsection{Holism}

Leonardo da Vinci (1452-1519) believed that it was important to understand the connections between the 'art of science' and the 'science of art'. His argument was that his success in one field was due to his understanding of how the other fields work, namely anatomy and art.

Science in the late 20th century realised that everything was interconnected. Particularly, the work of Lorenz (1996) indicated that a butterfly flapping its wings in Beijing could start a storm on the other side of the world. This was a key to the emergence of the New System Theory. Holism addresses and links traditions that are foreign to each other. It has no desire to be centralised, over-organised or hierarchical.

Green Economics and its development is in fact one of the most holistic and multidisciplinary economics the world has ever seen. There is no human activity, no part of the planet that is not of interest to Green Economics; it is the very economics of interconnectedness. Bloom's (2000) edited collections contain an interesting set of writers on this theme including, Fritjof Capra, Carl Jung, Carl Rogers, E.F. Schuhmacher, Louise Hay, the Boston Women's Health collective and Robert Graves.

As Harrison (1992, p.365) has argued, "The demands of the environment will present humanity with the challenge of breaking down the compartmentalisation of knowledge". Green Economics "could well become the science overarching all the others. As part of this, we desperately need an overarching science of human interactions, both with each other through an economic system and with the environment, combining socio-economic and technological studies with dynamic analysis of the physical environment". The Green Economics Institute will try to foster the realisation of Harrison's vision. 


\subsubsection{Attitudes to science}

Mainstream economics employs a set of positivist, modern tools to produce the desired strict and simple logic that is vital for a picture of the world purported to be the basis of economic thinking. But this is not necessarily a true reflection of reality. Reducing reality by the application of simplistic mathematical concepts appears to make the world more precise than it actually is. Commoner (1971, pp.97, 213) warned how modern technology caused intensifying 'assaults on the environment, creating a debt to nature ultimately leading to ecosystem collapse'. 'Modern technology extends man's effects on air, food and water, accumulating rubbish and junk.'

Green Economics adds verbal reasoning and description to the quantitative methods used to reflect the interconnectedness of the world. It may appear that Green Economics rejects scientific methods that are more precise and formal in their structure. The contrary is the case. The findings of science for example in climate change tend to support Green methodology; Green analysis is significantly based on science data, too.

Mainstream economics in spite of using quantitative methods is producing results that contradict insights from other sciences. It is focused on an infinite growth assumption, and on the belief that supposedly innate and uninfluenced consumer preferences should inform economic decision-making. It becomes increasingly evident that this is contradicting the scientific findings of ecologists (particularly climate change experts) and psychologists as far as consumption is concerned.

Green Economics is proposing to be a holistic, interdisciplinary, natural and social science, which chooses appropriate tools for each problem from its wide portfolio of methodologies. This is comparable to modern archaeology where precise natural scientific methods of carbon 14 dating are adopted; but equally so is narrative carefully applied to capture theories about the social dimension of people's lives as they were a long time ago.

Green Economics is economics that can accept and integrate differing positions on the world's big ideas, such as those presented in The New Scientist (Dawkins et al., 2005) The Big Bang, Evolution, Quantum Mechanics, Risk Theory, New System Theory, Relativity, Climate Change and Tectonics. Green Economics fundamentally incorporates the ideas of progress in scientific thinking and in scientific methodology. It is open and able to explore new ideas, which fundamentally change our perspective.

We contend that Green Economics alone inherently combines a scientific with a social science approach. The 'science' is not econometrics or mathematical economics at all, rather it is natural science, ecology and social science. Neo-classical economics has misused a narrow interpretation of Darwinism in order to justify capitalism, to advance the power of the strongest and fittest and to preserve inequalities.

Green Economics challenges the reductionism and supposed objectivity of mainstream economics. This agenda tends to prioritise capitalism as a specific style to run the economy, and supremacy of unadjusted market solutions at the expense of people's needs.

Environmental health, science and ecology have been formative influences on Green Economics. Busby (1995) and Lawson (1996) most potently illustrated Green Economics' treatment of the costs of nuclear power and climate change. 


\subsection{Political (structural/institutional)}

Thirdly, global corporations, are un-elected but are now more powerful than many nation states; yet their activities are unaccountable, such as those of Shell's in the Ogonni lands in Nigeria. They increasingly take the place of public decision-making, privatising and controlling important public assets including ownership of the water supply. Bakan (2004) describes corporations as psychopathic entities in their pursuit of profit and power. As argued by Tsakalotos (2005) “politically, 'Homo economicus' is interested in negative freedom, or minimising the interference from satisfaction of preferences of either the individual or the state and consuming private bundles of goods rather than investing in relationships".

Green Economics, influenced by such writers as Gramsci et al. is concerned with structural questions, such as the geographical scope of production for local needs, and exposing and combating the institutions and power structures that lead to poverty and lack of local control. It seeks to reinforce the local economy where appropriate. It particularly questions the role of oversized corporations, the quality of foreign direct investment and the strategy of global institutions, such as the IMF, WTO, GATTS and the World Bank. This article will show how, particularly, neo-classical economics has been used to reinforce a certain political structure and its related values.

The importance of incorporating political dimension into economics is clearly illustrated by the resistance to the Kyoto Protocol ratification (16 February 2005). Even more important and difficult than establishing the natural science data, are the problems of establishing the political will. "Ultimately, global warming adds to scientific dilemmas the questions of moral and global economics. It would require an estimated $2 \%$ of global GDP or 8 trillion US \$ to stabilise global warming" (Maslin, 2004, p.146).

Green Economics is also further influenced by the work of Gramsci (1932-1934), Polanyi (1944) and Braudel (1973) in attempting to explain the imposition of destructive, economic power in the socio-political order. Barry (1999a) argues that the de-embedding of the economy from other social, political and regulatory spheres was combined with the commoditisation process created by modern industrialisation. This combining was accompanied by the processes of enclosure and privatisation during the agrarian revolution, which forced people to sell their labour to owners of production who used the natural world as resource inputs. Labour and capital were free to move and be exchanged. This made it possible for new, unbridled institutions of economic exchange to grow into the dominant global corporations we have today, supported by the global institutions like IMF and World Bank and the G8, whose wishes are supported by the use of force.

Green Economics seeks to reconnect the values and costs of transactions with the natural world and with social structures. It seeks to enhance the local economy; supports bio-regional developments, democracy and access for all; and seeks global governance through new institutions designed for this purpose.

One example is the production of cash crops in developing countries to replace local food requirements, which require capital and thus leads to the constant necessity to service huge levels of debt. The consequence is increased dependency on the developed world and its institutions. The transformation of food production into a global agri-business controlled and owned by a small number of businesses, requiring large centralised control, is a structural concern. Shiva (1988) terms this 'mal-development' of patriarchal foundations. The products of such businesses are no longer for the benefit of society as a whole. Greenhalgh (2005) argues that in order to have sustainability, 
products should benefit the consumer, not just the owner of production. Green Economics argues that products should also benefit the community, society and the natural environment, and aims to develop and strengthen the appropriate political framework to achieve this.

\subsection{Moral}

One-fifth of the earth's 6.3 billion people are still trapped in life-threatening poverty (Sachs, 2005). About 2.8 billion people survive on less than \$2 per day (Brown, 2004, p.xv11). The UN reported that 30 million women and children throughout Asia and the Pacific have been trafficked over the past 30 years in the 'largest slave trade in history' and 40 million people in Africa risked starvation (Brown, 2004, pp.xxii, xxviii).

Contrary to textbook economics theory, the radical application of neo-liberal logic appears to be making matters worse for the world's poor. The opportunities for further exploitation are described by Harvard Business School (Prahalad and Hammond, 2003, p.1): " $65 \%$ of the world's population or four billion people earn less than $\$ 2000$ dollars per year; despite the vastness of this market, it remains largely untapped and revenue growth for multinationals entering them can be rapid, including more efficiency and low-cost labour". Offshoring and outsourcing are the new drivers of change and provide for increasing lack of transparency and exploitation.

Green Economics analyses the full impact of such theories for stakeholders and in contrast works for more, not less equity and more direct and just methods instead of relying on the unproven possibility that increasing consumption and wealth for the rich may trickle down to the poor. The result of current economic practise is that one-fifth of humanity as stated above live in abject poverty; and this proportion of systemic failure would never be tolerated, for example, in the case of cars or aeroplanes if one-fifth of them crashed or dropped out of the sky. We would insist on an investigation and a change in our basic production methods. Similarly, this failure ratio of the economic theory is completely unacceptable and explains why the basics need to be urgently rewritten.

Green Economics reincorporates earlier moral concerns into economics, in particular social and environmental justice, inclusiveness, equity and access. The appropriate scope to consider is the effect of a transaction on all stakeholders in using the widest definition, including the biosphere itself. Such a broad approach is not fully compatible with neo-classical logic nor can it be reconciled with the short-term logic of very large global corporations, which are required to maximise short-term profit for shareholders as Milton Friedman said in 1969 in Capitalism and Freedom, "the only social responsibility of business is to increase its profits". A new economics framework is needed that makes guns, the arms trade, human trafficking, prostitution and drugs less profitable and less common economic activities and provides 'safely and securely' for everyone's needs.

Economic, social and environmental justice, fairness and equity are the foundation on which Green Economics is built. The UN 1989 Convention on the Right of the Child divides rights into protection, basic provision of goods and amenities, and participation, which includes solidarity and community (UN Office of the High Commissioner of Human Rights, 1989, Preamble). Rights are defined as shared entitlements that promote equality, solidarity, social justice and peace. 
This differs from neo-classical concepts of rights and the allocation of resources, which assume self- interested individualism and market competition as the starting point for rights (Alderson, 2006). In Green Economics, the 'invisible hand' (Smith, 1776) is assisted by the use of data from natural sciences on resource potential and from social science about needs, rights, requirements and local conditions. An appropriate level of decision-making is encouraged, which allows access and transparency for everyone. New indicators, rather than just GDP (which only measures the quantity as monetary value of goods exchanged) show what the social and environmental justice targets could be, such as in education and literacy, and especially amongst women, work and unemployment, consumption, relative distribution of wealth and income, health, deforestation, natural assets, desertification, risk and trends, such as energy intensity (Anderson, 1991).

Green Economics is influenced by a number of thinkers who argue that poverty and inequality are linked and that improving equality will help end poverty now and for future generations. The basic needs of each person are paramount as described by Lord in An Introduction to a Citizens' Income (1999) and Max-Neef (1972). Max-Neef (1992) referred to nine basic needs: subsistence, identity, protection, affection, understanding, participation, leisure, creation and freedom. Sen's (1999) views are also that development and poverty relief are in themselves freedoms, and his capability theory expresses the idea that everyone should have what they need.

Table 2 Green treatment of selected problems

\begin{tabular}{|c|c|c|c|c|}
\hline & Ecological/Economic & Intellectual & Political & Moral \\
\hline $\begin{array}{l}\text { Climate } \\
\text { change }\end{array}$ & $\begin{array}{l}\text { Natural science } \\
\text { models, } \\
\text { Policy choices }\end{array}$ & $\begin{array}{l}\text { Long-term } \\
\text { Holistic } \\
\text { Natural science } \\
\text { data appreciated } \\
\text { Reduce demand }\end{array}$ & $\begin{array}{l}\text { Need for global } \\
\text { ratification } \\
\text { Specificity } \\
\text { of solutions } \\
\text { - temporal and } \\
\text { spatial }\end{array}$ & $\begin{array}{l}\text { Distribution of } \\
\text { effects and access } \\
\text { to energy use } \\
\text { Converge energy } \\
\text { use-equity }\end{array}$ \\
\hline Food & $\begin{array}{l}\text { Natural, local supply, } \\
\text { organic produce } \\
\text { No GMOs }\end{array}$ & $\begin{array}{l}\text { Right, needs } \\
\text { priority } \\
\text { Distributive } \\
\text { equity } \\
\text { Local } \\
\text { decision-making }\end{array}$ & $\begin{array}{l}\text { Local structure } \\
\text { versus } \\
\text { agribusiness } \\
\text { Local food } \\
\text { security }\end{array}$ & $\begin{array}{l}\text { Local } \\
\text { requirements } \\
\text { Need not } \\
\text { business } \\
\text { No animal } \\
\text { suffering }\end{array}$ \\
\hline Nuclear & $\begin{array}{l}\text { Cost of disposal } \\
\text { Accidents }\end{array}$ & $\begin{array}{l}\text { Intergenerational } \\
\text { equity/impacts } \\
\text { Long-term effects } \\
\text { on health }\end{array}$ & $\begin{array}{l}\text { Local choice of } \\
\text { renewable energy } \\
\text { solutions, new } \\
\text { technologies }\end{array}$ & $\begin{array}{l}\text { No imposition or } \\
\text { maintenance by } \\
\text { military }\end{array}$ \\
\hline Transport & $\begin{array}{l}\text { Use less, cut demand, } \\
\text { develop community } \\
\text { alternatives and local } \\
\text { facilities }\end{array}$ & $\begin{array}{l}\text { Use less, cut } \\
\text { demand, change } \\
\text { in attitude to } \\
\text { planning }\end{array}$ & $\begin{array}{l}\text { Regional } \\
\text { structure of } \\
\text { economy, } \\
\text { alternative means } \\
\text { of transport }\end{array}$ & $\begin{array}{l}\text { Share effects and } \\
\text { benefits } \\
\text { Structure viable } \\
\text { self-sufficient } \\
\text { communities }\end{array}$ \\
\hline
\end{tabular}


Schumacher (1973), arguing for an even distribution, was influential. Rawls' (1971) Theory of Justice is important. Justice in society can be agreed upon behind a 'Veil of Ignorance' whatever your position in society. Rawls borrows from Kant (1785) the deontological idea that the means of promoting justice are as important as the ends. This is partly because 'ends' are not guaranteed and therefore the precautionary principle even applies to principles of justice. Green Economics shows that environmental justice is not a 'luxury' because it is the poor who are disadvantaged first by environmental degradation.

\subsection{The development of Green Economics literature}

Carson (1962), probably the first Green writer, in Silent Spring criticised the chemical industry. An embryonic Green literature is evolving. Dobson (2000) in Green Political Thought lays the foundation of the overarching philosophy of Green political thinking and argues that "the ideology of ecologism is differentiated precisely because of its arguing for less consumption and it is this, which marks it off from light Green environmentalism: we can do more with less". Other early Green writers include Gruhl (1975) in Germany, Kelly (1994) Thinking Green; Porrit (1994) Seeing Green; Ekins et al. (2000) Wealth Beyond Measure; Kemball-Cook et al. (1986) The Green Budget; Douthwaite (1992) The Growth Illusion; and Shiva (1988). Shiva questioned how culturally perceived poverty (low GDP) where nature's and women's economy predominated was replaced by 'development', which caused a real material poverty, leaving 'less water, less fertile soil, less genetic wealth'. This was followed by Anderson's (1991) work on alternative indicators. Significant writers include Busby (1995) on nuclear and health, and Robertson (1999) on work. Scott Cato and Kennet (1999) co-edited an overview of the issues in Green Economics - Beyond Supply and Demand to Meeting People's Needs. Wall (2005) has explored the eco-socialist perspective and Lawson (1996) published on health issues, Brian Leslie on money issues, while Woodin and Lucas (2004) argued for economic localisation as their solution to globalisation. Lord (1999) developed the basic income scheme, Meyer Hillman argues for reduction in demand, and Mies (1994) has contributed the new subsistence perspective and patriarchy and accumulation argument.

\section{Main deficiencies in assumptions and conventions of neo-classical economics}

Green Economics argues that neo-classical economics is an instrument for social control, which imposes a set of values that does not maximise freedom or equity, and not even utility. We argue that these neo-classical values are the foundations for the commodification of nature and eventually for poverty. This section attempts to begin the analysis of the gaps, conventions, normative elements and deliberate bias existing in conventional economics. This assessment of what is wrong with the analyses, policies and recommendations of mainstream economics will be a main part of the academic and publication work of the Institute, to show that an alternative view is not only somehow desirable but fundamentally necessary, given the severe deficiencies of existing economic wisdom. The ideas, theories and concepts that have been developed in the past 200 years 
of economic thinking are so numerous that many articles will have to be written to explore what is still relevant and what needs adjustment. We will also have to address which ideas have relevance for our current economic situation and which have a tendency to preserve existing structures for the benefit of existing power elites but without much truth or objectivity from a scientific perspective.

Our main element of criticism of the so-called neo-liberal economic thinking is that it is first of all not 'neo' in any way, as it follows the traditional economic concepts usually referred to as classic economics, and tries to defend itself against any criticism suggesting that a different perspective might be possible or necessary. Secondly, there is doubt on the use of the term 'liberal' as this term seems to be very selectively used by conventional economists. Many of them criticise every attempt by politicians or economists to influence the automatic outcome of market forces as being anti-liberal, but they have very little to say about the behaviour of large multinational businesses, which is clearly outside liberal concepts of competition. The restriction of the international movement of the production factor labour (migration) that is supported by conservative sources does not attract the same criticism as do suggestions from green economists to manage international trade according to mutually beneficial rules.

Furthermore, it is simply foolish to form economic models with assumptions that are clearly contradicting knowledge from other sciences. This occurs most noticeably in the case of the fundamental limitations posed by ecological facts to economic practices.

We would argue that the terminology and assumptions used in conventional economics are value-laden, not value-free. For this introductory article, it must be sufficient to raise the question whether, for example, the use of ever increasing competitive pressure to force people to behave in a certain way is the same idea which the original proponents of liberal economic ideas had in mind when they demanded more freedom from undue interference by the state. The question of whether market forces generate or remove people's freedoms has to be addressed in a much more differentiated way. This includes a careful definition of the term "freedom", as well as scrutiny of the great potential for misuse if the term is not properly defined, or if a certain definition is simply assumed in model building.

The classical economic approach (Smith, 1776) was more often than not broad, diverse and philosophical in nature. Basic fundamental principles have been developed out of it to form the narrower and more conservative foundation of economics as a new science, which tends to misrepresent the original classical texts.

Furthermore, classical economics developed over time into a very scientific format where findings are allegedly independent of time and historic context, leaving the philosophical approach behind. Technical analysis of economic behaviour dominated the discourse (see Marshall, 1890), where the standard graphical analysis of the forces of supply and demand was defined. From then on, the focus on technical analysis and increased use of mathematics became more exaggerated. Despite all the limitations to the variety of methods accepted as properly scientific, mainstream economics is currently characterised by an unhealthy range of contradictory views and lack of consensus. In addition, realistic alternatives in the early stages of development do not receive the attention they deserve.

The various strains of this classical economic approach remained unchallenged for a long time until the demand-side revolution of Keynes (1936) presented an alternative view to the macro economy and its policies. The main innovation was a change in the belief that the economy will always be in the traditional situation of principal 
scarcity in the goods markets, which had been a fundamental assumption. Questioning this assumption threatened the entire stability of conventional economic thinking. Furthermore, the development of the real economy was different from the timeless classical concepts and this difference, between a non-evolutionary scientific approach and the actual economy understood as a historically changing process, contributed to the decline of classical economics. The reality moved on, although mainstream economists reiterated the same theories until the gap between theory and reality was undeniably wide and had to be filled with new ideas.

The Keynesian revolution was itself based on many similar mainstream assumptions and conventions, emphasising however the demand side of the economy. It therefore found itself prone to be outdated sooner rather than later. On a more general and philosophical level, a real alternative to the existing economic growth consensus (whether guaranteed via demand or supply-side policies does not matter much) emerged in the change of values in the 1960s when younger generations rejected this classical consensus of the purpose of life. On a more practical basis, demand-side management appeared to have been successful in overcoming the increasingly problematic business cycles. But when the economy found itself in a newly emerging longer-term demand crisis, Keynesian demand management resulted in high public debt, inflationary problems, poor growth rates and the demise of its influence on policy. Keynesian economics appeared to be itself dead in the long run. After Keynesian concepts lost power in the late 1970s, progressive economic thinking lost ground.

In short, the weakness of the Keynesian alternative was used to reinstate the very same classic concepts of an economy that will allegedly always develop in the same directions: more consumption and production, strict hierarchy of distribution of income to be maintained to keep the competitive spirit high, and acceptance of infinite human wants requiring higher productivity and rising incomes. What should have happened is a construction of an entirely new economic thinking based on the knowledge of contemporary social conditions, while respecting the fundamental limitations to economic activity and the changes in people's attitudes and factors of quality of life. New concepts that help to stabilise the economy independently from economic growth should have been introduced into the economic debate, including new concern about ecological limits, social justice, minorities and equal opportunities.

As the 1970s saw increased rates of inflation, - whether they really related to the Keynesian economic policies needs to be debated - the opportunity arose to destroy the Keynesian economic logic with the intention to reinstate the old normative conventions, now named 'monetarism'. Based on strictly conservative economic thinking by von Hayek (1944) and specific criticism about the movements of the Phillips curve (Phillips, 1958) towards higher inflation levels suggested by Milton Friedman, the old concepts and proposals re-emerged. Monetarism was still outside mainstream thinking when it was developed slowly in the 1970s. To affect the public debate, the proposals had to be distinct, simple and radical. This was later the downfall of this logic as the ideas proposed were formed to promote such a simple alternative for the political battleground that they later failed in reality quite quickly.

Because of the repeated failure of more progressive thinkers to use the weakening of the monetarist concepts to develop a sound response, today, concepts called neo-liberal are yet again on the agenda. Slightly changed conservative ideas are now regarded as undisputed truths about the economy, again without any relation to the true nature of the 
existing economic problems. An adjusted monetarism called neo-liberal, which was itself a version of the classical economic mainstream, emerged to fill the gap after the decline of monetarism. Neo-liberalism exists in the current vacuum of undeveloped alternatives. Particularly, politicians are following this trend without much interest in debating details or questioning the correctness of the proposals. It appears that a certain tiredness and laziness has affected economics. There is an undeniable lack of progressive thinking, a decline in the support for more sophisticated concepts like solidarity versus simple competition, or intelligent management of the economy versus letting the market forces run unregulated.

In recent times, practical knowledge derived from various central European countries already suggests that the proposed simplistic policies, based on the assumption that the same development path will be available to all societies indefinitely, do not deliver results; as a consequence, the neo-liberal agenda has begun to weaken. In a modern economy with an oversupply of goods, the scarcity moves towards the labour market (traditionally there was plenty of demand for labour but now there is unemployment as a consequence of lack of demand for labour) and away from the goods markets (traditionally there was a lack of supply of goods but now there is an oversupply of goods). Again the opportunity emerges to replace the constant reiteration of the same conceptually unchanged economic logic of unchanging traditional scarcity with rules derived from more appropriate economic knowledge. As the difference between the old logic and reality becomes greater yet again, and with the pressure and assistance of practical observation, the chances increase that a new stream of thinking can be started.

Neo-liberalism cannot be the final answer to the economic questions of today as it is a concept based on the desire to preserve an existing logic and normative way of living. It is not about finding out the truth about the world we live in, it is about creating an economic framework that only allows specific values to flourish. When progressive and holistic concepts are not properly considered, their consequences and findings are not utilised for better economic policies, and they are then rejected as allegedly not working in practice, despite the fact that they never had a chance to be correctly implemented. The failure to address the reality in an unbiased way and the inherent old-fashioned values that do not maximise human happiness within the conventional economic wisdom form show the need for the development of a truly scientific new approach. Green Economics is suggested as being the correct holistic and objective framework to develop this fundamental alternative and to help economic thinking out of its self-imposed gridlock. This gridlock debates the economics of existing power elites but not the economics of present reality.

\section{Sister disciplines and their contribution to Green Economics}

As a result of the lack of realism in neo-classical economic assumptions, other milestone attempts have been made to incorporate realistic environmental and social criteria into economics. In this section we examine the influence of some of these on the development of Green Economics ideas, which we argue has begun to provide a more complete, holistic and comprehensive picture of economic reality. 
Table 3 Sister disciplines which have influenced Green Economics

\begin{tabular}{|c|c|c|c|}
\hline \multicolumn{2}{|c|}{ Neo-liberal } & \multirow{2}{*}{$\begin{array}{l}\text { Radical/Participation/ } \\
\text { Anti-materialism }\end{array}$} & \multirow{2}{*}{$\begin{array}{l}\text { Holistic (Bloom), } \\
\text { Green/New philosophy }\end{array}$} \\
\hline Environmental & Social & & \\
\hline & & Socially Responsible & Subsistence economy (Mies) \\
\hline & & Investment (SRI) & The love economy (Henderson) \\
\hline & & & Eco-feminism (Shiva) \\
\hline $\begin{array}{l}\text { Environmental } \\
\text { economics } \\
\text { (Pearce) }\end{array}$ & $\begin{array}{l}\text { Welfare } \\
\text { economics } \\
\text { (Sen, Pigou) }\end{array}$ & Parecon (Albert) & Eco-socialism (Kovel) \\
\hline \multirow[t]{3}{*}{$\begin{array}{l}\text { Corporate social } \\
\text { responsibility }\end{array}$} & $\begin{array}{l}\text { Development } \\
\text { economics }\end{array}$ & $\begin{array}{l}\text { Anti-development } \\
\text { (Shiva) }\end{array}$ & $\begin{array}{l}\text { Buddhist economics } \\
\text { (Schumacher) }\end{array}$ \\
\hline & $\begin{array}{l}\text { Stakeholder } \\
\text { theory } \\
\text { (Freeman) }\end{array}$ & Trade justice movement & Deep Ecology (Naess) \\
\hline & & $\begin{array}{l}\text { Anti-globalisation } \\
\text { (Gramsci) }\end{array}$ & Industrial ecology (Korhonen) \\
\hline \multicolumn{2}{|c|}{$\begin{array}{l}\text { Sustainable development } \\
\text { (Brundtland) }\end{array}$} & Feminist (Mellor, Mies) & $\begin{array}{l}\text { Ecological economics } \\
\text { (Daly, Boulding) }\end{array}$ \\
\hline
\end{tabular}

\subsection{Welfare economics}

Welfare Economics recognises the shortcomings of a market economy, although still a neo-classical analysis. Negative external effects have to be defined by the authorities to monetarise them and to adjust the price mechanism accordingly. Pigou (1920) raised the question of divergence between social cost and private cost. The introduction of rights into the process of social choice poses new problems about motivations underlying individual preferences and the nature of the social alternatives. Green Economics questions whether distributive justice and efficiency are reconcilable without a market economy being specifically adjusted for this purpose.

\subsection{Buddhist economics}

Schumacher's (1976) arguments, in which he explored 'Buddhist' ideas, became the foundation stones for much Green activism and ecological awareness. The thesis was that industry and economic strategy had become so gargantuan that they had lost their humanity. Schumacher argued for methods and equipment that were "cheap enough so that they are accessible to virtually everyone, suitable for small-scale applications and compatible with man's need for creativity. Out of these characteristics is born non-violence and the relationship of man to nature, which guarantees permanence. If only one of these three is neglected, things are bound to go wrong". "The Buddhist is mainly interested in liberation." Schumacher questioned whether the path of economic development outlined by modern economics is likely to lead to a place where they really want to be. Norberg-Hodge's (1991) work is also influenced by Buddhism. 


\subsection{Environmental economics}

Environmental economics marked an important turning point in perception. It applies neo-classical economics to non-market phenomena or phenomena that are inevitably relevant to society and have at least partially an economic angle; for example, common resources, public goods, human decision making in a wider sense. Turner et al. (1993) and Mishan (1967) showed that these external negative effects ('externalities' of a social or environmental nature), being hard to capture, are the real costs of economic growth and should be included in the cost price. They suggested that production may actually result in an overall decrease in welfare. However, neither the profit motive nor market pricing nor competition was blamed for causing environmental destruction. Their approach regards simple moral normative tools as not necessarily effective, preferring instead instrumental tools that use the utility maximisation of the individual. Techniques include: Transferable emission and pollution permit trading; Environmental Resources Management; Pollution and Abatement costs control; Use of regulation, tax and markets; Market pricing and valuation of environmental services; Replacement cost approach; Hedonic pricing; Household production function; Travel cost method; Contingent valuation; Willingness to pay; Amenity rights; Coasian Property Rights (Coase, 1960); Cost-benefit analysis; and Positive discounting of the future (Pearce and Turner, 1990; Sen, 1999). The Hartwick-Slow method (Hussen, 2000) recognises the constraint of non-exhaustible renewables, but calculates human capital and natural capital (stocks of environmentally provided assets, such as soil, forest, wetlands, water) as substitutes, which thus permit continued real consumption of goods and services.

Green Economics appreciates this groundbreaking approach but argues that there is a high degree of intention in the construction of the models and concepts used. It maintains the status quo. It also avoids any real meaningful challenge to growth, to existing power structures, to issues of scale or ecological or resource impacts, or a more even distribution of income. Thus, new theories and concepts developed within the environmental economics paradigm are almost exclusively based on inadequate neo-classical foundations (Lawn, 2000).

\subsection{Green critique of sustainable development}

Sustainable development was defined by Brundtland (1987) as meeting "the needs of the present without sacrificing the ability of the future to meet its standards". The approach argues for a more enlightened globalisation to reach these standards and to resolve environmental degradation. Acknowledging that many nation states are weaker than global corporations, sustainable development argues in favour of benevolent corporations being the agents of global problem solving. The Stakeholder theory, (Freeman, 1994), (Jones et al., 2002), Corporate Social Responsibility (McIntosh et al., 2003; Hopkins, 1999) and its instrumental methodology are designed to provide significant competitive advantage for the firm when a subset of ethical principles (trust, trustworthiness and cooperation) are operationalised (Jones et al., 2002; Andriof and Waddock, 2002).

These theoretical perspectives have influenced and informed the perspective of important German and French Greens who are interested in the concept of 'other globalisation' and in exploring the idea that the implicit goals of economic theory and policy and action might be efficiency, value, human well-being, the 'good society', human values, and questioning the role of consumption as a proxy for utility (Ackerman 
et al., 1997). Elkington (1997), Zadek (2001), Wheeler and Sillanpaa (1997) and Welford and Gouldson (1993) have done influential and successful work in getting such approaches accepted in recalcitrant companies.

In contrast, many Green Economists regard corporations as agents of hegemony Gramsci (1932-1934), being undemocratic, unelected, uniform, lacking in transparency and being the fundamental causes of the problem. In privatising natural assets, corporations are represented as the unbridled, uncontrolled and unaccountable, fully destructive force of neo-liberal economics gone mad, 'pathological' as described by Bakan (2004) or by Korten (1997) in Corporations Ruling the World, Dicken (1986, p.236) questions whether transnational coporations should be regarded as 'beauty' or 'beast'. Even Milton Friedman (in Bakan, 2004, p.35) argues that the corporation would be 'immoral' to provide social responsibility to society. Green Economics seriously questions how it can be in a corporation's short-term interest to implement equity and environmental justice through the managerial 'environmentalist' approach of sustainable development. Dobson (2000) and Springett (2005b) criticise the short-term techno fixes, which on the one hand remain within the confines of the neo-classical paradigm, and on the other hijack environmentalism and the language of 'sustainability' (Welford and Gouldson, 1993) whilst at the same time working on 'backlash strategies' (Kennet, 1999; Breeder, 1997).

Sustainable development practices often get no further than the marketing/public relations department and fail to permeate other profit centres of a business, or to address economic inequalities or major social or environmental impacts. Sustainable development is regarded by Green Economists as an oxymoron, in reality often counteracting existing, local and community economic patterns. Greens instead seek to reverse the trends of neo-colonialism and large corporate destruction of local assets and replace them with new subsistence, local self-determination and community control (Norberge-Hodge, 1991; Mies and Shiva, 1993). Gigantism, monopolism and oligopoly are contrary to the Green Economics arguments for 'small, appropriate and diverse' developed by Schumacher (1973) and the localisation arguments of Hines (2000) and Woodin and Lucas (2004).

They also advise against huge, unelected, non-transparent, disembodied, neo-liberal, foreign direct investment monoliths in the form of corporations that assume the role of the state or act as moral arbiters of social and environmental justice or distributors of scarce resources, whilst engaged in their 'pathological' pursuit of power (Bakan, 2004).

\subsection{Ecological economics}

Ecological Economics regards the economy as a subsystem of a larger global finite ecosystem (which Boulding (1966) calls Spaceship Earth) and is subject to the laws of thermodynamics, entropy and to the conservation and dissipation of energy and demonstrated biophysical limits to growth (Constanza, 1991; Martinez-Alier, 1987). Ecological economics does recognise the interdependencies of the economic, social and ecological spheres, with the market being brought in only after equity and sustainability considerations are met, and only as a facilitator of the efficient allocation of resources. Markets are never used as an arbiter of (1) the equitable distribution of income and wealth creation or (2) the ecologically sustainable rate of resource use. Criticising neo-classical circular flow models, as too simplistic and too value-focused, Georgescu-Roegen (1966) also criticised existing scarcity and growth arguments as 
regulated by utility and by self-interest as mistakenly presumed to be independent of the natural world processes of matter and energy exchange. He described economic value as determined by demand (utility) and supply (technology and nature).

Daly (1974) modelled the 'Steady State Economy' that Mill (1859) had conceptualised as a 'Stationary State' and added biophysical and moral considerations. Daly's 'Means Ends Spectrum' described economic growth (producing more goods and services) to satisfy 'intermediate ends' as being finite. This is because resource scarcity cannot always be ameliorated through technology. Daly introduced concepts of 'constant stock' and 'throughput flows' durability, replaceability and recycleability, maintaining stocks of capital intact, with a minimal rate of production and consumption. If policy was focused on improving the stocks of capital (manufactured, social, human and natural capital), then (1) development can occur without the need for growth, and (2) the rate of resource throughput keeps the stock of capital intact and within the regenerative and waste assimilative capacities of the ecosphere. Also importantly, Daly stated that the trivial wants of some people do not take precedence over the basic needs of others (Hussen, 2000, p.258). The Safe Minimum Stock (SMS) Approach was developed by Ciriacy-Wantrup (1952) as a tool for maintaining a safe minimum level of scarce resources to prevent irreversible degradation of natural capital.

A fundamental stage in accepting the need for reform, Ecological Economics brought in realistic attention to complexity, value incommensurability and uncertainty in economy-ecology relations. It does, however, remain predominantly human-centred, although some ecological economists do take a more bio-centric world view where the scale of the economy does take into account the intrinsic values and needs of other species besides maximising the sustainable well-being of humans. However, Ecological Economics' emphasis is more biophysical and less economic or institutional than Green Economics, which incorporates these aspects and completely reworks economics with holistic, inclusive and long-term aims now moved to its core (Barry, 1999a).

\subsection{Heterodox economics}

Eichner (1978) emphasised methodological individualism, the doctrine that economic theories should be based on theories of individual behaviour rather than general equilibrium theory. Heterodox Economics was heavily influenced by von Mises, Menger and Hayek of the Austrian school and the Cambridge Journal of Economics is now a heterodox journal.

\subsection{Post-Autistic economics}

Sorbonne economist Guerrien (1989), together with a group of disaffected French and Cambridge students created the rather offensively named discipline. Green Economics supports its idea of allowing wider viewpoints. It deals especially with challenging neoclassical assumptions and incorporates sociological and psychological ideas, the utility theory, consumer choice, the production and efficiency theory, Pareto optimality, as well as the game theory. Subjects dealt with include Gross National Happiness, realism versus mathematical consistency, thermodynamics, irrelevance and ideology and the critique of the concept of homo economicus. Veblen (1904) is regarded as one of the most useful original thinkers. The group includes Heilbroner (2000), Daly (1974) and Galbraith (1999) who warned against 'an affluent society'. 


\subsection{Ecosocialism}

Eco-socialists believe that the destruction of the environment is a product of capitalist accumulation. They emphasise that it is the role of capitalism and its use of industry to produce for profit and not for need, rather than the role of industry itself, that degrades and destroys the means of production coming from nature (Dobson, 2000). Kovel et al. (2001) stresses that growth is ecologically unsustainable and a society based in meeting essential needs provides an alternative to capitalism. Ecosocialism and green philosophy are in many ways believed to be compatible, according to Barry (1999b).

Their manifesto argues for a valorisation of use-values over exchange values. Marx (1859) redefined value from the Ricardian definition (value means the price of a commodity), to Marx's definition (value means the labour time to produce a commodity). Marx's work, Das Kapital, analysed the tensions between capital and labour. Marx also predicted that capitalist production would become more centralised and more mechanised, which would lead to surplus value per unit of capital falling and with it the rate of profit. Capitalism would offset this by increasing the exploitation of workers and making them work more intensively (Backhouse, 2002). The surplus value per unit of capital argument has been criticised early on by, for example, Schumpeter (1912).

The Green Economics perspective is altogether different as both Marx and Schumpeter follow the logic of increased production without limits, and are concerned with the distribution of income and its effects for the survival or replacement of the economic system. The Green Economics perspective does not seek to replace one large edifice or 'Grand Narrative', capitalism with another, Marxism or Socialism; and criticises industrialism as a whole rather than just capitalism.

\section{How Green Economics is beginning to take shape}

\subsection{Philosophical principles, background influences and roots}

\subsubsection{Enlightenment}

The aims of the enlightenment were liberty, solidarity and equality, all of which Green Economics would support. The ecological point of view builds on enlightenment ideas of reason and the rights and preferences of logical and rational economic man. Backhouse (2002) explains that it was an age of tolerance, liberty and progress, a revolt against what was seen as 'unreason or obscuritanism', especially against religion. In this way, the roots of the Green theory favour what is secular and scientific and also espouse democracy, freedom, tolerance, equality and other rational values that owe their roots to the enlightenment.

However, through the primacy and separation of reason and knowledge from wisdom, the idea of dualisms disembodied and denied what we experience as a part of the whole. This is extremely apparent in economics and contributes to current problems in this discipline relating to human community, nature, the biosphere and the planet. Poles of acceptability or unacceptability were created - rational or irrational, people or nature, male or female, rational or emotional, mind or matter, physical or spiritual and science or art. This disembodiment and polarity are the opposite of holism, which Green Economics seeks to restore. 
Smith argued that people are born with a moral sense and a sense of natural fellow feeling or sympathy with others in the community. In An Enquiry into the Nature and Causes of the Wealth of Nations (1776), he argued that there should be a social revolution. He believed that we have evolved from savage hunters through nomadic agriculture and feudal farming, finally having potential for perfect liberty, which meant wages were determined by the market in a laissez faire economy whose benefits would flow down to the poor. In terms of quality however, some green economists think that the early pre-agricultural stages can inform us about distribution, power and fulfilment of the needs of the community.

The enlightenment works of Locke (1561) to Newton, Bacon, Montesquieu's The Persian Letters (1689-1755), Voltaire and Diderot have provided influences. Rousseau's (1754-1762) earlier idea was that children were born innocent and he blamed culture and knowledge for inequality. He was very concerned with nature and believed property caused the ills of society. Kant (1785) provided a critical foundation to the kind of knowledge we find in natural science, separating the phenomena or appearances from what we find in the moral law, appealing to reason, peace and progress. Voltaire emphasised religious tolerance and free speech. Mill was important in realising, after the French revolution, that the rise of community power can be as despotic as the monarchy. His work, On Liberty, (1859) was concerned with protecting the rights of the individual as well as of the community. Green Economics always seeks to enhance the well-being of the community and its economy but in every case attaches huge importance to the needs, rights and well-being of individuals rather than their egoistic preferences. In addition, in Principles of Political Economy, Mill suggested that a Stationary State was a better view of social progress. "The best state... is that no one is poor, no one desires to be richer.... It is only in the backward countries that increased production is still an object, in the most advanced, what is economically needed is better distribution" (Mill, 1848).

\subsubsection{Critical theory}

Adorno et al. were responsible for the introduction of the Critical Theory in the 1930s at the Frankfurt School, being heavily influenced by Hegel and Marx. They challenged the recent empirical approach of the natural sciences. They argued that science, technology and rationality were implicated in domination over external nature and that the very process of enlightenment imprisons man who is himself part of nature. Marcuse (1964) argued that we should make a concerted effort to reduce consistently the suffering that man imposes on the natural world. However, Barry (1999b) points out that neither ecology nor the non-human world nor social-environmental relations were Marcuse's central themes. Baskar (1998) described the hidden inequalities of power elites.

Habermas (1995) argued that social order is the distinction between the 'lifeworld' and the 'system', comprising economics, markets and the state. The term lifeworld described informal and unmarketised domains of social life, family, culture and political life outside of social organisations, such as political parties, mass media and voluntary organisations. Not hostile to the state or the market economy as such, Habermas did warn that they steer us towards ends that are not widely understood or consensual, but he saw progress as premised on the instrumental use of the natural environment (Barry, 1999a). 
When strategic decisions are left to markets, a whole host of what Habermas calls 'social pathologies' arise, including the negative effects on the non-market domains they colonise, such as decrease in shared meanings and mutual understandings, erosion of social bonds and alienation.

Discourse theorists, such as Foucault (1969) suggest it is not truth that counts but rather who defines truth and what uses it is put to. Knowledge is used in the exercise of power. This argument is used to deconstruct the role and power of globalised companies who argue for norms and standards, which they realise only they can meet in the marketplace and which exclude local and smaller companies. This is an example of how observers and researchers are never neutral and neither is any account of history, making it essential to reveal the originating perspective in order to discover the intended meaning of words and arguments.

\subsubsection{Post-modernism}

Post-modern ideas seem to be completely missing from mainstream economics. Gergen (2001) argues that post-modernism is just a form of academic turf war between sections of liberal arts and the sciences. However, we would argue that even if we don't accept their conclusions, the complete refusal to address post-modern concerns misses important developments in human thought, and might, at least in part, account for the old-fashioned aspect of neo-classical economics and its current difficulties.

In particular, the prevalence of the Western-dominated, white, middle class, homo economicus experience as the standard model in economics has left out the experiences of most people in the world.

In this way, the work of such writers as Derrida (1978) is extremely helpful as he rejects single narratives and investigates whether reality is fact, truth, myth, interpretation or one person's view of events. Derrida has helped in analysing the workings of binary oppositions and dualisms, such as West and East, feminine and masculine, light and dark, civilised and primitive, them and us, to criticise the power structures in which they are embedded. This work is useful in unravelling neo-colonial economic arguments.

\subsubsection{Feminist economics}

There are two economic stories, that of competitive production and exchange in markets and that of care, reciprocity, direct production and maintenance of human beings. One of the main contributions of feminist economics is the notion that production does indeed occur in the home or 'okia'. The Greek root of economics refers not to the office or factory but to the home: the site of physical, affective and mental production (Feiner, 2003). Important feminist influences have been Waring (1988), Salleh (1997), Nelson (2003), Starhawk (1979), Mies (1994), Mellor (1992) and Henderson (1983). Their approaches warn against theories that legitimise a single-gendered homo economics version or 'story' of reality that ignores and also excludes gynaika ekonomika from the public economic sphere. Feminist methodologies allow us to dig into the way in which the foundations of a discipline are laid and then expose them as particular and contingent, and to warn against drawing generalisations of meaning of 'outside' and 'difference' on others' behalf. It reveals the placing of boundaries in economics as an intensely political act. It reminds us that the notion of free choice applies only to those with the economic power and freedom to apply it (Kaul, 2003). 
Feminist economics has opened debate about the pivotal role of women in the formal global economy (Mies, 1994) and found further evidence of patriarchy and exploitation. Women have been used to provide unpaid, non-valued, invisible 'non-economic, free, resource foundations'. Mellor (1992) discusses what women's work (paid and unpaid) means for the world economy and how it affects the women who do it. The discipline of economics has had less and less to do with their experience and reality. Kelly (1994), the influential German Green, wrote, "Feminism is about alleviating women's powerlessness. Women must share half the earth and half the sky. There is a clear relationship between militarism, environmental degradation, and sexism."

Mellor (1992) shows that the physical arena of the body is not wanted by economics. It is treated as a cost. Cartesian dualisms and the separation of body and mind have cast women in the realm of the body and its emotions, and men in the realm of the mind. The formal sector of exchange value, which is supposedly moral-free, is highly valued by society, providing personal wealth, using skilled labour, intellect and exploitable resources. However, the informal sector, caring work or work of the body has no exchange value, is women's work, concerned with feelings, emotions, sickness, needy, old and young people, eco-systems and wild nature and is called the love economy (Henderson, 1983). Waring (1988) related this work to the overarching system of formal reckoning in the economy of the GNP.

Feiner (2003, p.186; Mellor, 1992) compare a mother's satisfaction of her infant's insatiable needs with similar patterns of adult consumption in the market in a capitalist society, and with rational male minds choosing exchange for satisfaction and a denial of sharing.

Feminist economics also brings into the exchange arena the concept of morals and removes dualisms from concepts of economics, science and values (Nelson, 2003).

Mies (1994) showed that patriarchal and capitalist exploitation leads to capital accumulation. Her theories find particular resonance with Green Economics in questioning why a product should be produced or consumed at all. If a product's sole rationale is simply to reinforce power of any kind, Green Economics argues that it is not necessary. The resources of the earth, local communities and households should not be wasted in order to create it.

The production of new workers and the body of old or young, sick or pregnant workers are not considered worth valuing or counting, in an exchange economy and are outside the homo economicus experience, except as part of the consumer market. There is a direct relation here to work by Sykes (2002) about the coming of agriculture (civilisation), which enabled patriarchy, accumulation and dominance to be possible using the new-found surplus agriculture had generated. In contrast, the work of the arms and the sex industries all have meaning for homo economicus and a source of exploitative power and domination.

Mies (1994) also noted that, in industrial societies, housework was not counted as work, either by capitalist economists or by socialist ones. Mies even found that Marx's concept of productive labour was reserved mainly for male breadwinners in factories, directly producing exchange - and surplus - value for the capitalist market. Women's invisible role as reproductive workers reproducing the working class from day to day and inter-generationally was ignored. This invisible labour and housewifisation, as if it is secondary income and trivial, is still indeed the optimal labour for capitalism because it 
remains free of costs. The new world of outsourcing, offshoring and contract labour takes advantage and extends the model to men as well as women. Mies' (1994) famous Iceberg model shows that many of the inputs for an economy that used the capitalist or industrialist style are goods that do not show up above the waterline of visibility.

\subsubsection{The influence of the limits to growth perspective}

Meadows (1972) argued in The Limits to Growth that rapidly diminishing resources force a slowdown in industrial growth due to a rise in the death rate and a decrease in food supply and medical services. Despite greater material output, the world's people will be poorer than they were. This collapse occurs because of non-renewable resource depletion. Growth would be stopped well before 2100, caused by overloading of the natural absorptive capacity of the environment. The models were influential and Meadows suggested using technology to get around the problems.

Carson's (1962) book Silent Spring showed the devastating effects of chemicals on the natural world. She highlighted the effects on bird's eggs, which led to a silent spring. She says the obligation to endure gives us the right to know and to stop using such chemicals. This genre is followed up by such books as Chemical Children by Mansfield and Munro (1987) and Ehrlich's (1969) article on the dangers of an increasing population in The Population Bomb.

The debate tends towards the view that certain absolute limits must be imposed to save people from themselves. It harks back to Malthus (1798) and issues raised by Hardin (1968) in The Tragedy of the Commons, but the debate also questions the root of technological fixes, end-of-pipe solutions and, one could argue, Environmental Economics and corporate social responsibility. In fact one green view is that in raising fulfilment of women, in most cases, the birth rate plummets. Therefore, the overpopulation may really be the result of the imbalance in the position of women in society. A green economics perspective educates but does not prescribe.

The aim of a Green Economy is that each person has enough to live on without exploiting other people or resources, and the amount and style of work is commensurate with that. Important influences have been: Morris's (1883) ideas of satisfying and non-mechanised work describing the three hopes of work (rest, pleasure and product) and Robertson (1999) researching into the future, meaning and relevance of work.

\subsubsection{Green Economics and the role of nature}

Over the last few hundred years, mainstream economics has tamed and used nature as an expendable given resource, and has only valued scarce resources. Nature is abundant and therefore has been treated as a 'free good' and resource, and has been disregarded even though it is becoming more apparent that nature holds up the world economy and it is becoming more visibly fragile and 'scarce'. Goldsmith (2005) shows that Environmental Economics does attempt to adjust neo-liberal economics to the needs and costs of nature. However, this only works if the adjustments are small, whereas if it tries to adjust to the whole of nature's carrying capacity, which Goldsmith argues it does, then clearly the discipline of economics needs to be rewritten in order to include and to take into account the role of nature. This is the work of Green Economics. 
Georgescu-Roegen (1966) described the fact that there is a continuous mutual influence between economic processes and the natural world that carries no weight within standard economics. White (1967) criticised Western attitudes to nature and attributed them to the influence of Christianity on the development of technology and assumption of human mastery through the taming of the natural world. He argued that Christianity has 'desacralised' nature, encouraged its exploitation and promoted a world view in which humans are superior to the rest of nature. The enlightenment also tended to look for logic and reason rather than wisdom in nature.

This attitude is illustrated by Bacon in Thomas (1983): "The human mind which overcomes superstition is to hold sway over a disenchanted nature. What men want to learn from nature is how to use it in order to wholly dominate it and other men. That is the only aim."

Green Economics argues that nature has its own intrinsic value, which it extends to animals based on the ethics of Singer (1975/1985) in Practical Ethics, who argued for the rights of all sentient beings. Green Economics extends this to all life forms. Stone (1972) in Should Trees Have Standing? formulates the legal standing of the rights of nature and the biosphere based on Lovelock's (1979) The Gaia Hypothesis. Leopold (1949) and Naess (1995) on Deep Ecology argue for the preservation of the biosphere, geological and biological systems and all life forms for their own sake not only for human benefit, criticising anthropocentric ethics and the 'shallow anthropocentric technocratic environmental movement', which is concerned primarily with pollution, resource depletion and the health and affluence of people in the developed countries (Sessions, 1995, p.xii). Green Economics combines Deep Ecology with an anthropocentric ethic, seeking to preserve the natural life forms and systems.

\section{Conclusion: unique insights and findings so far}

Green economics specifically sets out to develop a new approach to deal with social and environmental problems on a global scale. The most pressing of these are the huge extent of poverty and the rapid depletion and disruption of the earth's resources. Specifically, the conduct of multinational enterprises is a paramount concern if a more just, sustainable and equitable world is going to be developed.

Green Economics is uniquely placed to offer to solve such problems, as its Green background makes it comfortable with its inherent natural science, and its grounding in social and environmental justice makes it sit equally comfortably within the social sciences.

This paper has attempted to set the scene for the development of a Green Economics discipline, approach, or school of thought and also for a new way of doing economics and it is in the process of developing its own philosophical basis and policies to implement its ideas. The article has summarised some of the important philosophical influences and roots that are contributing to the development of this philosophy, including from sister disciplines. It has also presented some of Green Economics' defining features, such as long-termism and holism. 
At the heart of Green Economics is the need to integrate the community, all people everywhere, nature and women and to acknowledge for the first time the true role they all play in the economy. Current economics simply regards them as free goods to be used up, annihilated and squandered in pursuit of the consumption of industrialised goods and services for profit. In the main, this kind of economics reflects the wants and preferences of Western-educated white middle-class males and their power structures, corporations and global institutions delivered by means of neo-classical economic theory, which reinforces that position.

Green Economics therefore reconstructs reality using knowledge from the sister disciplines described above, together with the full range of academic and research knowledge and puts it together holistically. It regards climate change not so much as a cost problem but as part of nature, and solving climate change itself, Green Economics argues, will contribute to solving economic problems, not the other way around. Removing and mitigating the economics effects is not an ambitious economic goal. Green Economics seeks to change the situation and believes that economics will benefit from this attitude and therefore the resultant costs will be much lower.

It also acknowledges the structural reasons for the anthropogenic climate change, and the political, structural and power elite obstacles, preventing change and is able to formulate a framework for unblocking this. It argues therefore for sound scientific qualitative and social science research, holistically put together, to advance economics to take a much more practical role.

Above all, it completely reforms economics to be an activity in which everyone and everything on the planet practises and reveals how they all have requirements and impacts, which we need to understand and manage properly.

One-fifth of our own species starving in poverty is completely unacceptable and a failure of massive dimensions, which Green Economics sets out to work to solve and argues that solving this and the problems of other species extinction, the 'Biocide', are all part of the same failure to understand how everything is interconnected and 'different' from the white male middle-class 'Grand Narrative' of capitalism or Marxism. It argues against dogma and externally imposed systems, believing that local economic control, access, survivability and diversity are key.

The science data shows that survival is an issue for humans and a change in planetary conditions are challenging the rationale of conventional economics, with its own practitioners seeking new answers. We believe that Green Economics with its sound, multidisciplinary basis and which is attracting innovative thinkers, can also provide a real benefit to the mainstream economics discipline and help in its complete reform or as Goldsmith says, "Rewriting of economics". We believe it is the aims and goals of economics that need to be revisited and overhauled, and words like profit, growth, progress, development, economics, etc. should be completely redefined so that they can provide what we all need. The axis of owner versus the worker presented by Marxism and Capitalism is outdated and far too narrow. Green Economics presents a new axis of all people everywhere, society, non-human species, the biosphere and the planet, they all matter and they must all urgently be incorporated in our economic assessment. Economics must move away from reliance on models that design a simple ceteris paribus world on paper to more complex scientific models, which simulate the real world, such as those developed to explain climate change with enormously revealing consequences. 
Green Economics advises that since the earth's environments are complex and diverse, then diversity and complexity should become a strong feature of economic systems and no imposition of dogma should occur or overrule local decision-making.

Research is providing sound, well-researched and detailed new perspectives in the way we can look at supply and demand, the roles and effects of such current practises as offshoring, outsourcing and other aspects of industrialisation. Green Economics has a characteristic long-termism, much longer than short-term business cycles, and so aims to ensure that future generations' needs are met and not plundered by neo-classical discounting of future assets. It also differs in its treatment of preferences, growth, markets and equilibrium, and it seeks to manage and regulate where the market fails to provide the right solution.

Green Economics argues for sweeping, new ecologically based attitudes to consumption and work. It is framed around concern for equitable distribution of resources and power within and between societies. Due to its strong natural science roots, it observes and accepts that all resources are not just scarce but finite.

Green Economics is beginning to provide a sorely needed fresh and radical approach, to the complete reform of economics, its aims, methods, scope and context. It seeks to reclaim the word 'equilibrium' from its narrow neo-classical use. For example, chopping down a rainforest and using all the wood up or selling it, green economics would term as 'destruction' not 'growth'. Green Economics reserves the term 'growth' for things that really grow and are abundant and thus does not seek to destroy or to cost that destruction (as in environmental economics). It seeks to avoid destruction. In this sense, Green Economics provides a truly radical departure even from most of its sister disciplines.

Increase in the GDP of a country is not described as growth or progress by Green Economics, if many of its people remain hungry, its resources are removed or its women trafficked and forced into prostitution. Additionally, half of all products and services globally are in the unpaid sector, which Henderson (1999) has pointed out is worth 16 trillion dollars, all of which has been missing anyway from the GDP figures. So, economics as it has been before has been only half understood and half accounted for. In this way, Green Economics puts the reality back into the theory, re-centres and re-absorbs such work as Economics and comes up with what we have argued is a much more useful working concept.

This article has examined the roots of Green Economics, which are extremely eclectic and diverse. The scope is truly global, its methods innovative and its context long-term and holistic. The aims are nothing less than the re-establishment of true 'planetary equilibrium' of benefit to and also between individuals, peoples, communities, nations, genders and non-human species, nature, the planet and the biosphere whilst also maintaining such equilibrium with and within nature, the planet and the biosphere.

\section{Acknowledgements}

The authors would like to thank the following for their contributions and comments to this article: Victor Anderson, Rose Bridger, Marie Nicholsby, Barbara Weinberg, Jacob Sanders, Dr. John Barry and Professor Priscilla Alderson, Professor Andrew Dobson, Peter Lang, Dr. Derek Wall, Dr. Philip Lawn, Katherine Kennet, Brian Heatley and Dr. Delyse Springett. 


\section{References}

Ackerman, F., Kiron, D., Goodwin, N., Harris, J.M. and Gallagher, K. (1997) Human Well-being and Economic Goals, CA: Island Press.

Alderson, P. (2006) 'Economics, inequalities and childhood: outlining the jigsaw puzzle', International Journal Childhood.

Anderson, V. (1991) Alternative Economic Indicators, London: Routledge.

Andriof, J. and Waddock, S. (2002) 'Unfolding stakeholder thinking', Theory, Responsibility and Engagement, Sheffield, Greenleaf, UK.

Arrow, K. (1951) Social Choice and Individual Values, Yale University Press, 1970.

Backhouse, R. (2002) The Penguin History of Economics, London: Penguin.

Bakan, J. (2004) The Corporation - The Pathological Pursuit of Profit and Power, Constable.

Barry, J. (1999a) Environment and Social Theory, London: Routledge.

Barry, J. (1999b) Marxism and Ecology, in A. Gamble, et al. (Eds.) Marxism and Social Science, Macmillan, pp.259-280.

Barry, J. (1999c) Rethinking Green Politics: Nature, Virtue and Progress, London: Sage.

Baskar, R. (1998) Critical Realism-essential Reading, London: Routledge.

Bloom, W. (2000) Holistic Revolution, Allen Lane, London: Penguin Press.

Boulding, K.E. (1966) The Economics of the Coming Spaceship Earth, in H.E. Daly (Ed.) Towards a Steady State Economy, San Francisco, W.H. Freeman and Company, 1973.

Braudel, F. (1973) Capitalism and Material Life, Nicholson and Weidenfeld.

Broswimmer, F. (2002) Ecocide - A Short History of the Mass Extinction of Species, Pluto Press Sterling.

Brown, L. (2004) Progress Towards a Sustainable Society, World Watch Institute-State of the World, London: Earthscan.

Brundtland, G.H. (1987) Our Common Future World Commission on Environment and Development, OUP, pp.1-11.

Busby, C. (1995) The Wings of Death - Nuclear Pollution and Human Health, Aberystwyth, Green Audit.

Carson, R. (1962) Silent Spring, Houghton Mifflin.

Coase, R. (1960) 'The problem of social cost', Journal of Law and Economics, October, pp.1-44.

Commoner, B. (1971) The Closing Circle, Nature, Man and Technology, Kopf, NY, pp.267-276.

Constanza, R. (1991) 'Embodied energy and economic valuation', Science, Vol. 210, pp.1219-1224.

Ciriacy-Wantrup, S. (1952) Resource Conservation Economics and Policy, University of California Press.

Daly, H.E. (1974) 'The economics of the steady state', American Economic Review (Papers and Proceedings), May, Vol. 64, No. 2, pp.15-21.

Dawkins, R., Rees, M., Randall, L. and Deutsch, D. (2005) 'Great ideas that shaped our world', New Scientist, 17 September.

Derrida, J. (1978) Writing and Difference, University of Chicago Press.

Dicken, P. (1986) Global Shift, Industrial Change in a Turbulent World, London: Harper and Row.

Dobson, A. (2000) Green Political Thought, Abingdon: Routledge.

Douthwaite, R. (1992) The Growth Illusion, Resurgence.

Ehrlich, P. (1969) The Population Bomb, Ballantine.

Eichner, A.S. (1978) A Guide to Post-Keynesian Economics, M.E. Sharp. 
Ekins, P. and Max-Neef, M. (1992) Real Life Economics - Understanding Wealth Creation, London: Routledge.

Elkington, J. (1997) Cannibals Without Forks - The Triple Bottom Line of 21st Century Business, Capstone, Oxford.

Feiner, S. (2003) 'Reading neo-classical economics: towards an erotic economy of sharing', in D. Barker and E. Kuiper (Eds.) Towards a Feminist Philosophy of Economics.

Foucault, M. (1969) The Archaeology of the Mind, London: Routledge.

Freeman, R.E. (1994) Strategic Management - A Stakeholder Approach, Boston: Pitman.

Friedman, M. (2000) Capitalism and Freedom, University of Chicago Press, 1969.

Galbraith, J.K. (1999) The Affluent Society, Penguin, 1958.

Georgescu-Roegen, N. (1966) 'The entropy law and the economic problem', in H.E. Daly and K. Townsend (Eds.) Valuing the Earth: Economics, Ecology, Ethics, Cambridge, MA: MIT Press.

Gergen, K.J. (2001) 'Psychological science in a postmodern context', American Psychologist, Vol. 56, pp.803-813.

Goldsmith, E. (2005) Rewriting Economics, www.greeneconomics.org.uk (accessed 17 January 2006).

Gramsci, A. (1932-1934) Some Theoretical and Practical Aspects of Economism, http://www.marxists.org/archive/gramsci/editions/reader/q13-18.htm (accessed 17 January 2006).

Greenhalgh, C. (2005) 'Why does market capitalism fail to deliver a sustainable environment and a greater equality of incomes?', Cambridge Journal of Economics, OUP, December, Vol. 29, No. 6.

Gruhl, H. (1975) Ein Planet Wird Gepluendert, S. Fischer, Germany.

Guerrien, B. (1989) 'L'economie neoclassique', Economica.

Habermas, J. (1995) The Philosophical Discourse of Modernity.

Hardin, G. (1968) The Tragedy of the Commons, Science, Vol. 162, pp.1243-1248.

Harrison (1992) The Third Revolution, in Nelissen, van der Straaten and van den Klinkers (1997) Classics in Environmentalism, The Netherlands: International Books.

Heilbronner, R. (2000) The Worldly Philosophers - The Life and Times of Great Economic Thinkers, London: Penguin.

Henderson, H. (1983) The Warp and the Weft, the Coming Synthesis of Ecophilosophy and Ecofeminism, in L. Caldecott and S. Leland (Eds.) Reclaim the Earth, The Women's Press.

Henderson, H. (1999) Small is Beautiful, 25 years later with commentaries, in E.F. Schumacher, Vancouver: Hartley and Marks.

Hines, C. (2000) Localisation: A Global Manifesto, London: Earthscan.

Hopkins, M. (1999) The Planetary Bargain: Corporate Social Responsibility Comes of Age, MacMillan Press.

Houghton, J. (1997) Global Warming the Complete Briefing, 2nd ed., Cambridge University Press.

Hussen, A. (2000) Principles of Environmental Economics, London: Routledge.

Jevons, W.S. (1871) The Theory of Political Economy, R.D. Black Harmondsworth (Ed.), Penguin Books, 1970.

Jones, T.M., Wickes, A. and Freeman, R.E. (2002) 'Stakeholder theory - the state of the art', Bowie Business Ethics, Blackwell Publishers.

Kant, E. (1785) Metaphysics and Morals.

Kaul, N. (2003) 'The anxious identities we inhabit, positivisms and economic understandings', in Kuiper and Barker (Eds.) Towards a Feminist Philosophy of Economics, London.

Kelly, P. (1994) Thinking Green - Essays on Environmentalism, Feminism and Non-Violence, Parallax Press. 
Kemball-Cook, D., Baker, M. and Mattingley, C. (1986) The Green Budget, Green Print.

Kennet, M. (1999) 'Backlash: strategies used by big business to meet the environmental challenge', in M. Scott Cato and M. Kennet, Green Economics-Beyond Supply and Demand to Meeting People's Needs, Aberystwyth, Green Audit.

Kennet, M. (2004) 'How do current purchasing methods in large international companies affect stakeholders? Research to investigate the effect of purchasing trends and practices on people and the planet', Corporate Social Responsibility and Environmental Management Conference, University of Nottingham Jubilee Campus, 28-29 June, Conference proceedings.

Kennet, M. (2005a) 'How do the current purchasing and supply chain methods in large international companies affect stakeholders? Contrasting stakeholder theory and Green Economics using a holistic approach', Conference Proceedings, Devonshire Hall, University of Leeds Business and Sustainable Environment, 4-6 September.

Kennet, M. (2005b) 'Parecon - participatory economics', in D. Springett (Ed.) Sustainable Development, Wileys, Interscience and ERP Environment, Vol. 13, No. 4, pp.268-270.

Keynes, J.M. (1936) The General Theory of Employment, Interest and Money, Macmillan Cambridge University Press.

Kitson, M. (2005) 'Economics for the future', Cambridge Journal of Economics, Oxford University Press, Vol. 29, No. 6.

Korten, D. (1997) When Corporations Rule the World, Kumarian Hartford.

Kovel, J., Lowry, M. and Shearsby, W. (2001) An Ecosocialist Manifesto, http:/www.joelkovel.org/ (accessed 17 January 2006).

Lawn, P. (2000) Towards Sustainable Development, Boca Raton: CSR Press.

Lawson, R. (1996) Bills of Health, Oxford: Radcliffe Medical Press.

Leopold, A. (1949) A Sand County Almanac, Oxford University Press.

Lord, C. (1999) An Introduction to a Citizens Income, in Scott Cato and Kennet.

Lorenz, R. (1996) The Essence of Chaos, Routledge.

Lovelock, J. (1979) The Gaia Hypothesis - A New Look at Life on Earth, OUP, pp.1-12.

Malthus, T.R. (1798) 'An essay on the principles of population, in Nelissen, van der Straaten and van den Klinkers, Classics in Environmentalism, Utrecht: International Books, 1997.

Mansfield, P. and Munro, J. (1987) Chemical Children, London: Century.

Marcuse, H. (1964) One-dimensional Man, in G. Ward, Postmodernism, Hodder Education, 2003.

Marshall, A. (1890) Principles of Economics, 8th ed., London: Macmillan, 1920

Martinez-Alier, J. (1987) Ecological Economics: Energy Environment and Society, Cambridge, MA: Basil Blackwell.

Marx (1859) A Contribution to the Critique of Political Economy, Das Kapital.

Maslin, M. (2004) Global Warming a Very Short Introduction, Oxford University Press.

Max-Neef, M. (1972) 'Development and human needs', in P. Ekins and Max-Neef, Real Life Economics-Understanding Wealth Creation, London: Routledge.

McIntosh, M., Thomas, R., Leipziger, D. and Coleman, G. (2003) Living Corporate Citizenship, Harlow: Prentice Hall.

Meadows, D. (1972) The Limits to Growth; A Report for the Club of Rome's Project on the Predicament of Mankind, 2nd ed., New York: Universe Books.

Medena, S.G. and Samuels, W.J. (1996) Foundations of Research in Economics, Edward Elgar.

Mellor, M. (1992) Breaking the Boundaries Toward Feminist Green Socialism, Virago.

Mies, M. (1994) Patriarchy and Accumulation on a World Scale, Women and the International Division of Labour, London: Zed Books.

Mies, M. and Shiva, V. (1993) Ecofeminism, Zed Books.

Mill, J.S. (1848) Principles of Political Economy. 
Mill, J.S. (1859) On Liberty, Penguin Classics, 1974.

Mishan, E.J. (1967) The Costs of Economic Growth, in Nelissen, van der Straaten and van den Klinkers, International Books, 1997.

Mithen, S. (2003) After the Ice a Global Human History $20000-5000$ BC, London: Phoenix.

Morris, W. (1883) Useful Work Versus Useless Toil, http://www.marxists.org.uk/archive/morris/ works/1885/useful.htm (accessed 17 January 2006).

Myers, N. (1985) The Gaia Atlas of Planet Management, Good Books.

Naess, A. (1995) 'Deep ecology', Deep Ecology for the 21 st Century, Shamballa.

Nelson, J. (2003) How Did the Moral Get Split from the Economic?, in Kuiper and Barker (Eds.) pp.134-143.

Norberge-Hodge, H. (1991) Ancient Futures Learning from Ladakh, Sierra Club Books.

Omerod, P. (1994) The Death of Economics, London: Faber.

Pasinetti, L. (2005) 'Cambridge school of Keynesian economics', Cambridge Journal of Economics, Oxford University Press, December, Vol. 29, No. 6.

Pearce, D.W. and Turner, K. (1990) The Economics of Natural Resources, Harverster Wheatsheaf.

Phillips, A.W.H. (1958) 'The relation between unemployment and the rate of change of money wage rates in the United Kingdom, 1861-1957', Economica NS, Vol. 25, No. 2, pp.283-299.

Pigou, A.C. (1920) The Economics of Welfare, London: Macmillan.

Polanyi, K. (1944) The Great Transformation, Boston: Beacon Press.

Porrit, J. (1994) Seeing Green the Politics of Ecology Explained, London: Blackwell.

Prahalad, C.K. and Hammond, A. (2003) 'Serving the world's poor profitably', Harvard Business Review on Corporate Responsibility, Harvard Business School Publishing.

Rawls, J.A. (1971) A Theory of Justice, Harvard University Press.

Robertson, J.A. (1999) A Green Benefits and Taxation System, in M. Scott Cato and M. Kennet, Aberystwyth.

Rousseau, J.J. (1762) Emile, London: Dent, 1911.

Sachs, J. (2005) The End of Poverty - How we Can Make it Happen in our Lifetime, London: Penguin

Salleh, A. (1997) Ecofeminism as Politics, Nature Marx and Postmodernism, London: Zed Books.

Schumacher, E.F. (1973) 'Small is beautiful', in W. Bloom, Holistic Revolution, Penguin Press, 2000.

Schumpeter, J.A. (1912) Theorie der Wirtschaftlichen Entwicklung, Leipzig, Duncker and Humblot, The Theory of Economic Development, English translation, Cambridge, MA: Harvard University Press, 1934.

Scott Cato, M. and Kennet, M. (1999) Green Economics: Beyond Supply and Demand to Meeting People's Needs, Aberystwyth, Green Audit.

Sen, A. (1999) Development as Freedom, Oxford.

Sessions, G. (1995) Deep Ecology for the 21st Century, Shambahla Publications.

Shiva, V. (1988) Staying Alive, Women Ecology and Development, Zed Books.

Singer, P. (1975/1985) 'Defence of Animals', in Singer, Ethical Studies, Practical Ethics in Bowie, Nelson Thornes, 1994, p.301.

Smith, A. (1776) The Theory of Moral Sentiments and The Wealth of Nations, Penguin, 1986.

Springett, D. (2004) 'Structural limits to sustainable development: companies and progressive agency', Corporate Social Responsibility and Environmental Management Conference, Nottingham University, 28-29 June, Conference proceedings, pp.300-309.

Springett, D. (2005a) 'Managing sustainable development, discipline of an "inefficient concept", IJGE. 
Springett, D. (2005b) 'Structural limits to sustainable development: companies and progressive agency', International Journal of Innovation and Sustainable Development, Vol. 1, Nos. 1-2, pp.127-152.

Starhawk (1979) The Spiral Dance, Harper and Row.

Stone, C.D. (1972) 'Should trees have standing, in towards legal rights for natural objects', Southern Californian Law Review, pp.450-501.

Sykes, B. (2002) The Seven Daughters of Eve, Corgi Books.

Thomas, K. (1983) Man and the Natural World - Changing Attitudes in England, 1500-1800, London: Penguin Books.

Tsakalotos, E. (2005) 'Homo economicus and the reconstruction of political economy: six theses on the role of values in economics', Cambridge Journal of Economics, December.

Turner, K., Pearce, D. and Bateman, I. (1993) Environmental Economics, An Elementary Introduction, FT Prentice Hall.

UN Office of the High Commissioner of Human Rights (1989) Convention on the Rights of the Child, General Assembly Resolution 44/25, Geneva, 20 November.

Veblen, T.B. (1904) Theory of Business Enterprise, New York: Scribners.

von Hayek, F.A. (1944) The Road to Serfdom, London: Routledge.

von Neumann, J., Morgenstern, O. and Kuhn, H. (2004) The Theory of Games and Economic Behaviour, Princeton Classics.

Wall, D. (2005) Babylon and Beyond, London: Pluto Press.

Walras, L. (1865) Elements of Pure Political Economy.

Waring, M. (1988) Counting for Nothing, Sydney: Allen and Unwin.

Welford, R. and Gouldson, A. (1993) Environmental Management and Business Strategy, Pitman Publishing.

Wheeler, D. and Sillanpaa, M. (1997) The Stakeholder Corporation, Pitman Publishing.

White, Jr., L. (1967) 'The historical roots of our ecological crisis', Science, Vol. 155, No. 3767, pp.1203-1207.

Woodin, M. and Lucas, C. (2004) Green Alternatives to Globalisation, Pluto Press.

\section{Bibliography}

Anderson, V. (1999) Can There be a Sensible Economics?, in M. Scott Cato and M. Kennet, Green Audit, Aberystwyth.

Barker, D. and Kuiper, E. (2003) Toward a Feminist Philosophy of Economics, London: Routledge.

Barry, J. and Doherty, B. (2002) 'The greens and social policy: movements, politics and practice', in M. Cahill and T. Fitzpatrick (Eds.) Environmental Issues and Social Welfare, Blackwell, pp.119-140.

Bateman, I. (1995) 'Environmental and economics appraisal', in O. Riordan, Environmental Science for Environmental Management, Addison Wesley Harlow.

Breder, S. (1997) Global Spin - The Corporate Assault on Environmentalism, Devon: Green Books.

Brulle, R. (2003) 'Habermas and green political thought - two roads converging', Environmental Politics, Winter, Vol. 11, No. 4.

Chit, C. (2006) 'Restoring the rights of future generations', Internatioal Journal of Green Economics, Vol. 1, No. 1, Geneva and Milton Keynes, Inderscience.

Dow, A.C. and Dow, S. (2005) 'The application of development economics general principles and context specificity', Cambridge Journal of Economics, OUP, Vol. 29, No. 6. 
Ekins, P., Hillman, M. and Hutchinson, R. (2000) Wealth Beyond Measure - An Atlas of New Economics, Gaia Books.

Field, B. (2001) Environmental Economics an Introduction, McGraw Hill.

Finlayson, G. (2005) J. Habermas, a Very Short Introduction, Oxford.

Goldsmith, E. (1972) Blueprint for Survival, in Nelisson, van der Straaten and van den Klinkers, Utrecht: International Books, 1997, p.200.

Heinemann, V. (2001) The Economy of the Future, Die Oekonomie der Zukunft, Grundlagen und Elemente Fuer Eine Langfristige Gesellschaftliche Strategie, Hamburg, Books on Demand.

Horrocks, C. and Jevtic, Z. (2002) Introducing Foucault, UK: Icon Books Royston.

Kennet, M. (1999) 'An introduction to Green Economics', in Scott Cato and M. Kennet, Green Economics-Beyond Supply and Demand to Meeting People's Needs, Aberystwyth, Green Audit.

Korhonen, J. (2004) 'Theory of industrial ecology', International Journal of Industrial Ecology, Vol. 1, Nos. 1-3.

Nelissen, N., van der Straaten, J. and van den Klinkers, L. (1997) Classics in Environmental Studies, International Books.

Pareto, V. (1906) Manual of Political Economy, Manuela di Economia Politica, Audustus M. Kelly Publications, 1969.

Pearce, D.W. (1994) 'Foundation of ecological economics', Ecological Modelling, Vol. 38, pp.9-18.

Pratten, S. (2005) 'Economics as progress, the LSE approach', Cambridge Journal of Economics, March, Vol. 29, pp.179-205.

Redclift, M. (1987) Sustainable Development Exploring the Contradictions, Routledge.

Samuels, W.J. (1992) Essays in the History of Heterodox Political Economy, Palgrave Macmillan.

Screpanti, E. and Zamagni, S. (2005) The Outline of the History of Economic Thought, Oxford.

Sertiglanges (1992) Leonardo da Vinci (1452-1519), Muse Clos Luce, Amboise: Museum of da Vinci Publication.

Sim, S. and van Loon, B. (2001) Introducing Critical Theory, Royston: Icon Books.

Spencer, L. and Krauze, A. (1997) Introducing the Enlightenment, Royston: Icon Books.

Springett, D. (2006) "Contesting "the business case" for sustainable development: a New Zealand perspective', in R. Welford, P. Hills and W. Young (Eds.) Partnerships for Sustainable Development: Perspectives from the Asia-Pacific Region, University of Hong Kong, April.

Springett, D. and Foster, A.B. (2005) 'Whom is sustainable development for? Deliberative democracy and the role of unions', Sustainable Development, Vol. 13, pp.271-281.

Ward, G. (2003) Teach Yourself Post Modernism, Hodder Education.

Woker, R. (2001) Rousseau, a Very Short Introduction, Oxford.

Zadeck, S. (2001) The Civil Corporation - The New Economy of Corporate Citizenship, Earthscan.

\section{Note}

1 http://www.solarviews.com/cap/earth/earthafr.htm 